\title{
IJJM
}

Ilomata International Journal of Management

P-ISSN: 2714-8971; E-ISSN: 2714-8963

Vol. 1 No. 2 March 2020 pp. $72-77$

https://www.ilomata.org/index.php/ijim

\section{The Effect of Brand Associations and Brand Awareness on the Decision to Buy a Sim Card}

\author{
Yayuk Yuliana ${ }^{1}$, Mardi Giwa Putra ${ }^{2}$ \\ ${ }^{1}$ Marketing Management Muslim Nusantara University, Medan \\ ${ }^{2}$ Faculty of Economics, Muslim Nusantara University, Medan \\ Correspondence: yayukyuliana@umnaw.ac.id
}

Submitted: February $16^{\text {th }}, 2020 \quad$ Revised: March $12^{\text {th }}, 2020 \quad$ Published: March $30^{\text {th, }} 2020$

\begin{abstract}
In the rapid development of technology, the business world required to compete in this globalization era. The company expected to keep abreast of technological developments accompanied by producing goods that are under the times and are full of innovation. Consider, a cellphone is a necessity item that cannot be separated from daily life, of course, causing increasingly fierce competition between cellular operators to attract the attention of consumers to want to use and remain loyal to their products. The basis for think of this research with its longterm goal of creating a close and healthy relationship with consumers through brand equity. In the context of creating loyal customers, the task of marketers is always not focused on the effort to practice the marketing mix as the primary strategy. The short-term goal is to analyze the influence of brand awareness and brand associations. Concerning Sim cards, more and more choices of goods and services make possibilities moving brands are higher, customers are less loyal, so they need to get attention. The results obtained that three variables have a significant effect partially, namely brand associations with a significance value of probabilities as $\alpha$ of 0,000 $<0.05$ while the calculated value $>\mathrm{t}_{\text {table }}$ is $8.871>0.1996$. The results of the $\mathrm{t}$-test calculation of the Brand Awareness variable obtained the significance value of the probability $\alpha$ of $0.223>0.05$ while the cost of $\mathrm{t}_{\text {count }}<\mathrm{t}_{\text {table }}$ is $-2222<0.1996$.
\end{abstract}

Keywords: brand associations, brand awareness, Purchasing Decisions, sim card, technology

\section{INTRODUCTION}

Business competition in the era of rapid technological development today is no longer a product quality war but a brand war. Product quality has become a standard that can be easily and quickly copied and owned by anyone. At the same time, the only attribute that is difficult to replicate is a strong brand that can provide guidelines, guarantees, confidence, and expectations in creating customer satisfaction.

One of the most appropriate competitive strategies is to increase brand equity to maintain customer loyalty. Brand equity is significant for marketers, and the level of brand loyalty from customers becomes its primary support. In reality, many brands are considered as an identity only to distinguish them from competitors. Therefore the company needs to sharpen its paradigm, not only trying to achieve customer satisfaction but more on achieving customer loyalty Bhote, in Dicho et all (2016).

Companies will be more easily recognized if the company is right in naming a brand, making it easier for customers to distinguish their products and to make repeat purchases. One way to win the competition is a war between brands because marketing itself not only markets 
The Effect of Brand Associations and Brand Awareness on the Decision to Buy a Sim Card

Yuliana, Putra ${ }^{2}$

the product. Still, a memorable brand will make consumers' perceptions positive about the product.

Marketers build brand equity by creating the right brand knowledge structure for the right consumer. This process relies on all brand-related contacts, whether done by marketers or not. Brand equity has several dimensions, according to Aaker in Dicho et all (2016), consisting of Brand Awareness and Brand Associations.

According to (Kotler and Keler, 2009: 240), purchasing decisions are consumers' decisions regarding preferences for brands in a collection of choices. According to Astuti and Cahyadi (2007), if a customer is not interested in a brand and buys because of the characteristics of the product, price, comfort, and with little concern for the brand, the possibility of brand equity is low. Whereas if customers tend to buy a brand even though faced with competitors who offer superior products, for example, in terms of price and practicality, then the brand has a high equity value Astuti and Cahyadi (2007).

This condition makes competition more competitive, which will make consumers become selective in making purchasing decisions and even quickly move to other brands. Influencing consumer purchasing decisions is closely related to brand equity. If the brand equity of a product is stable and preferred, the tendency of consumers to buy products repeatedly will occur. For this reason, researchers are interested in researching the title The Effect of Brand Awareness and Brand Associations on Purchasing Decisions on Sim Card.

\section{METHOD}

Respondents to be examined are regular students who are active in the 2015 and 2016 faculty of economics at UMN Al Washliyah Medan. Primary data from this study were obtained from data collection by survey method carried out by going directly to the field by distributing questionnaires to respondents. Primary data is data that is collected by an organization or individual directly from its object (Santoso and Tjiptono, 2001). Besides, secondary data obtained through literature studies from literature and journals relating to issues, economic magazines, and other information can retrieve through the on-line (internet) system.

The population in this study used all regular students of the Faculty of Economics, University of Muslim Nusantara Al Washliyah Medan class of 2015 and 2016. As the research population amounted to 244 people (according to data from the Student Affairs Department of the Faculty of Economics UMN AW). Students who are the object of research are specifically for S1 regular students of 2015 and 2016. While the sample, according to Arikunto (1998), says that the example is part of the population (part or representative of the population under study). The sample of this study is a portion of the people taken as a source of data and can represent the entire population. Sampling According to Hair et al. in Dicho at all (2016), the number of samples obtained from a ratio of 20: 1 , where each one variable requires 20 respondents. This study uses five variables so that the number of respondents needed is 100 respondents. The method in sampling is a non-probability sampling; that is, a sampling technique that does not provide equal opportunity for each element or member of the population to select as a sample (Sugiyono 2010). The prerequisite for non-probabilities in this study is the UMN Faculty of Economics students who use cellulite or sim card products. 
The Effect of Brand Associations and Brand Awareness on the Decision to Buy a Sim Card Yuliana, Putra ${ }^{2}$

\section{Definition of Variable Operations}

\begin{tabular}{|c|c|c|}
\hline Variable Name & Definition & Indicator \\
\hline \multirow{4}{*}{$\begin{array}{l}\text { Brand } \\
\text { Awareness }\end{array}$} & \multirow{4}{*}{$\begin{array}{l}\text { Brand awareness is the ability of a } \\
\text { prospective buyer to recognize or } \\
\text { recall that a brand is part of a } \\
\text { particular brand category } \\
\text { (Aaker, 2003) }\end{array}$} & This sim card is a famous brand \\
\hline & & $\begin{array}{l}\text { This sim card is the best-prepaid } \\
\text { starter }\end{array}$ \\
\hline & & card \\
\hline & & $\begin{array}{l}\text { This sim card is the leading choice } \\
\text { when you want to buy a product }\end{array}$ \\
\hline \multirow[t]{7}{*}{ Brand associations } & \multirow{7}{*}{$\begin{array}{l}\text { Brand associations reflect the } \\
\text { bonds of consumers between } \\
\text { brands and essential product } \\
\text { attributes, such as logos, slogans, } \\
\text { or well-known personalities } \\
\text { (Grewal and Levy, 2008: } \\
280 \text { ). }\end{array}$} & I recognize this sim card product \\
\hline & & based on the logo \\
\hline & & I recognize this sim card product \\
\hline & & based on the slogan \\
\hline & & $\begin{array}{l}\text { This sim card has many features } \\
\text { available }\end{array}$ \\
\hline & & e as needed \\
\hline & & $\begin{array}{l}\text { This sim card has a stable jar } \\
\text { everywhere }\end{array}$ \\
\hline \multirow[t]{13}{*}{ Purchasing Decisions } & \multirow{13}{*}{$\begin{array}{l}\text { According to Kotler and } \\
\text { Armstrong } \\
\text { (2008: 181) understanding } \\
\text { purchasing } \\
\text { decisions are buying the most } \\
\text { preferred } \\
\text { brand, but two factors can be } \\
\text { between } \\
\text { purchase intentions and purchase } \\
\text { decisions }\end{array}$} & $\begin{array}{l}\text { The suitability of the type of } \\
\text { product }\end{array}$ \\
\hline & & purchase to the needs \\
\hline & & The suitability of the form of the \\
\hline & & card with the smartphone owned \\
\hline & & $\begin{array}{l}\text { Buy a sim card because the brand } \\
\text { is }\end{array}$ \\
\hline & & superior to competitors \\
\hline & & $\begin{array}{l}\text { Easy to buy because there are } \\
\text { sellers }\end{array}$ \\
\hline & & everywhere \\
\hline & & Buy the desired amount of credit in \\
\hline & & accordance with the nominal \\
\hline & & Buy credit/data packages at any \\
\hline & & time when necessary \\
\hline & & $\begin{array}{l}\text { Ease of payment by cash / non- } \\
\text { cash }\end{array}$ \\
\hline
\end{tabular}

\section{RESULTS AND DISCUSSION}

SIM Card is a card that we use to subscribe to one cellular operator. SIM is an abbreviation of the Subscriber Identity Module. This smart card produced in the form of Integrated Circuit (IC), which stores data for GSM (SIM Card) and CDMA (RUIM Card) cellular phone customers. The SIM Card function is a small information card that contains subscription information and other personal information. 
The Effect of Brand Associations and Brand Awareness on the Decision to Buy a Sim Card

Yuliana, Putra ${ }^{2}$

Table 1. F- test results

\begin{tabular}{llrrrrr}
\multicolumn{7}{c}{ ANOVAa } \\
\hline \multirow{2}{*}{ Model } & Sum of Squares & df & \multicolumn{2}{c}{$\begin{array}{c}\text { Mean } \\
\text { Square }\end{array}$} & F & Sig. \\
& & & & & \\
\hline $\mathbf{1}$ & Regression & 1219,536 & 4 & 304,884 & 120,076 & $.000^{\mathrm{b}}$ \\
\cline { 2 - 7 } & Residual & 241,214 & 95 & 2,539 & & \\
\cline { 2 - 7 } & Total & 1460,750 & 99 & & & \\
\hline
\end{tabular}

a. Dependent Variable: Purchase Decision

Testing the effect of independent variables together on the dependent variable is done using the $\mathrm{F}$ test. The results of the statistical calculation show the ${ }_{\text {calculated }} \mathrm{F}$ value $=120.076$ with a significance of $0.000<0.05$. This means that together brand awareness, brand association, has a significant influence on the decision to buy a sim card.

Table 2. T-test results

\begin{tabular}{|c|c|c|c|c|c|c|}
\hline \multirow[t]{3}{*}{ Mode } & & \multirow{2}{*}{\multicolumn{2}{|c|}{$\begin{array}{l}\text { Unstandardized } \\
\text { Coefficients }\end{array}$}} & \multirow{3}{*}{$\begin{array}{c}\text { Standardized } \\
\text { Coefficients }\end{array}$} & \multirow[t]{3}{*}{$\mathbf{t}$} & \multirow[t]{3}{*}{ Sig. } \\
\hline & & & & & & \\
\hline & & $\mathrm{B}$ & Std. Error & & & \\
\hline \multirow[t]{3}{*}{1} & (Constant) & -2.256 & 1,359 & & $-1,660$ & .100 \\
\hline & Brand Awareness & -.112 & .91 & -.070 & -1.227 & .223 \\
\hline & Brand Association & 1,005 & .113 & .589 & 8871 & .000 \\
\hline
\end{tabular}

a. Dependent Variable: Purchase Decision

\section{Effect of Brand Awareness on Purchasing Decisions}

The hypothesis, which affirms brand awareness influences purchasing decisions, is unacceptable (rejected). Proves that the brand awareness Based on analysis of data obtained in the t-test, the result coefficient of -0.070 so that the variables Brand Awareness is not a significant and negative effect on the decision of purchase (Y). Evidenced by the acquisition of the substantial value of the alpha probability of $0.223>0.05$ and $t$-value of $-1.227<0.1996$.

Although the results of majority respondents' answers score both in terms of recognizing, remembering, and being aware of the existence of these products, none of that is a reason in making a purchase decision.

These results are in line with research from Iriani (2011) and Rahmadhano (2014) that the Brand Awareness variable $\left(\mathrm{X}_{1}\right)$ has no significant and negative effect on purchasing decisions (Y). Students' need for communication in this era of the internet has become famous in choosing which provider can provide the best quality in terms of strong signals, fast internet, and low data/pulse package prices. Based on the results of research on student respondents, it found that the need for internet data packages is far more important than the use of communication (telephone/SMS). It can show from the need for internet data quota provided by a small sim card so that respondents decide not to buy. 
The Effect of Brand Associations and Brand Awareness on the Decision to Buy a Sim Card

Yuliana, Putra ${ }^{2}$

\section{Effect of Brand Associations on Purchasing Decisions}

Hypothesis, which states brand associations are positively influential on

Purchase decisions are accepted. Proves that brand Associations Based on the results of data analysis obtained in the t-test, received the coefficient value of $\mathrm{X}_{2}$ of 0.589 so that the variable Brand Associations $\left(\mathrm{X}_{2}\right)$ has a significant and positive effect on purchasing decisions (Y). Evidenced by the acquisition of a significance value of $\alpha$ probability of $0,000<0.05$ and $\mathrm{a}_{\text {calculated }} \mathrm{t}$ value of 8.871>0.1996. According to Sangadji and Sopiah (2013: 324), the association is an attribute that already exists in a brand and will be higher if the customer has a lot of experience dealing with that brand.

The sim card association has various attributes and full features and is under current developments. Then it can be concluded that students who use sim cards due to the confidence that arises when using this product also have features available that suit the needs of students. Results from the four most dominant variables that affect the dependent variable are the variable Brand Associations $\left(\mathrm{X}_{2}\right)$, the acquisition value of $\mathrm{t}_{\text {count }}$ high of 8.871>0.1996, a decrease significance value of $0,000<0.05$ and the highest beta coefficient of 0.589 .

\section{CONCLUSION}

Brand awareness does not have a significant adverse effect on purchasing decisions. It is due to the need for internet data packages offered by sim cards that do not meet the needs of students of the faculties of economics in 2015 and 2016. Providers must retain consumers to continue using sim cards and direct consumers to have data packages enough internet.

The coefficient of determination obtained was 0.835 . This means that $83.5 \%$ of purchasing decisions can explain by the brand awareness and brand association variables. In comparison, the remaining $16.5 \%$ sim card purchasing decisions influenced by other variables not examined in this study.

It should be more careful in determining the choice of consumer products. Because a lot of advertisements offered by providers with the terms and conditions that apply but consumers are less aware; should establish positive communication with the provider, so that retailers or traders know consumer complaints, one of them is by utilizing after-sales activities, namely claims against the provider in the event of a reduction in consumer confidence in the product, to maintain loyalty by providing a suggestion box service provided by the provider at the counter The closest counter

\section{REFERENCE}

Aaker, David A. (2003). Brand Equity Management, Primary Partner Publisher, Jakarta.

Aisyah, W. U. N., Salim, F., \& Sofyan, M. (2019). The Influence of Service Quality and Price on the Interest of Commuterline KRL Passengers. Ilomata International Journal of Management, 1(1), 13-18. Retrieved from https://www.ilomata.org/index.php/ijim/article/view/29/29.

Candra Johan (2014). The Influence of Promotion Factors, Product Quality, and Dissatisfaction with Brand Transfer. Journal of Management Science, 2(3).

Dicho, P., et al. (2016), Brand Equity Influence on Purchasing decisions, Journal of Business Administration (JAB), 34 (1).

Fadli \& Inneke Qomariah (2008). Analysis of the Influence Factors of Honda Brand Motorcycle Brand Equity on Purchasing Decisions (Case Study at the University of North Sumatra). Journal of Business Management, 1(2), Medan. 
The Effect of Brand Associations and Brand Awareness on the Decision to Buy a Sim Card

Yuliana, Putra ${ }^{2}$

Grewal, Dhruv., \& Levy, Michael (2008). Marketing. New York: The McGraw-Hill Companies.

Technisiana. (2015). Telkom Indosat Q3 2014 Financial Performance Report Xl .

Kotler, Philip., \& Armstrong, Gary (2008). Principles of marketing. Interpreting Bob Sabran. Jakarta: Erlangga, Publisher.

Kotler, Philip., \& Keller, Kevin L. (2009). Marketing Management. Issue 13. Bob Sabran. Jakarta: Erlangga, Publisher.

Kotler, Philip., \& Keller, Kevin L. (2012). Marketing Management. 14th ed. England: Prentice Hall, Inc.

Mowen, John C., \& Minor, Michael (2002). Consumer Behavior. Interpreting Dwi Kartini Yahya. Jakarta: Erlangga.

Sangadji, Etta, M., \& Sopiah (2013). Consumer Behavior: A Practical Approach. Yogyakarta: CV Andi Offset.

Sugiono (2012). Qualitative and Quantitative Research Methods and R \& D, Bandung: Alfabeta

Sunyoto, Danang (2013). Theory, Questionnaire, and Data Analysis: For Marketing and Consumer Behavior. First edition. Yogyakarta: Graha Science. 